\title{
TEORI INSTITUSIONAL DALAM PENYUSUNAN DAN PUBLIKASI LAPORAN TAHUNAN SEKTOR PUBLIK (STUDI KASUS PADA KEMENTERIAN DAN LEMBAGA NEGARA DI INDONESIA)
}

\author{
Joko Kisworo \\ Elvia Rosantina Shauki \\ Universitas Indonesia \\ Alamat Korespondensi: joko.kisworo@ui.ac.id
}

\begin{abstract}
The annual report, which is internationally recognized as an important tool for accountability and for delivering good information, has only been prepared by a few Ministries / State Institutions (MS/I) in Indonesia. This results in a lack of transparency and a lack of community participation. This study uses an institutional theory approach. It aims to analyze the differences in MS/I motivation in the preparation and publication of annual reports and formulate efforts to increase that motivation. This research is a case study research by exploring the phenomena that occur in the preparation of MS/I annual reports and institutional factors that become the background. Data collection was carried out by distributing open-ended question questionnaires to Data and Information Management Officers from 86 MS/I. Respondents' answers were analyzed using content analysis techniques, thematic analysis, and constant comparative analysis. The results showed that the dominant logic is symbolic carriers at the national level, that is the logic that the preparation of annual reports is an "obligation" to implement the Act. Material carriers affect only the routines factor while relational systems and artifacts are not found to be constrained. Normative isomorphism occurs in all MS/I that are respondents of the study, while coercive isomorphism and mimetic isomorphism occur in 60\% of MS/I. To encourage motivation for the preparation of annual reports, the government must prepare a clear regulation, standardized guidelines, internal SOPs, and implement annual report awards.
\end{abstract}

\section{KATA KUNCI:}

Public Administration, Public Sector Annual Report, Institutional Theory, Isomorphism

\begin{abstract}
ABSTRAK
Laporan tahunan yang dikenal oleh dunia internasional sebagai alat akuntabilitas dan sarana penyampaian informasi yang baik, hanya disusun oleh sedikit Kementerian/Lembaga Negara (K/L) di Indonesia. Hal ini mengakibatkan kurangnya transparansi dan kurangnya partisipasi masyarakat. Penelitian ini menggunakan pendekatan institutional theory dan bertujuan untuk menganalisis perbedaan motivasi K/L dalam penyusunan dan publikasi laporan tahunan dan merumuskan upaya untuk meningkatkan motivasi tersebut. Penelitian ini bersifat penelitian case study dengan menggali fenomena yang terjadi dalam penyusunan laporan tahunan K/L dan faktor-faktor institusional yang menjadi latar belakangnya. Pengumpulan data dilakukan dengan menyebarkan kuesioner open-ended question kepada Pejabat Pengelola Data dan Informasi dari $86 \mathrm{~K} / \mathrm{L}$. Jawaban dari responden kemudian dianalisis dengan menggunakan teknik content analysis, thematic analysis, dan constant comparative analysis. Hasil penelitian menunjukkan bahwa logika dominan adalah symbolic carriers di tingkat nasional yaitu adanya pandangan bahwa penyusunan laporan tahunan adalah suatu "kewajiban" untuk melaksanakan Undang-Undang. Material carriers yang berpengaruh hanya dari faktor routines sementara relational systems dan artifacts tidak ditemukan kendala. Normative isomorphism terjadi di seluruh K/L yang menjadi responden penelitian, sedangkan coercive isomorphism dan mimetic isomorphism terjadi di $60 \% \mathrm{~K} / \mathrm{L}$. Untuk mendorong motivasi penyusunan laporan tahunan, pemerintah harus mempersiapkan payung hukum, pedoman terstandard, SOP internal, dan melaksanakan ajang penghargaan laporan tahunan.
\end{abstract}

\section{KLASIFIKASI JEL:}

H11 


\section{CARA MENGUTIP:}

Kisworo, J. \& Shauki, E. R. (2019). Teori institusional dalam penyusunan dan publikasi laporan tahunan sektor publik (studi kasus pada kementerian dan lembaga negara di Indonesia). Indonesian Treasury Review: Jurnal Perbendaharaan, Keuangan Negara dan Kebijakan Publik, 4(4), 305-321.

\section{PENDAHULUAN 1.1. Latar Belakang}

Tata kelola pemerintahan yang tidak baik (poor governance) merupakan penyebab utama buruknya kinerja ekonomi berbagai negara di masa lalu (The World Bank, 1989). Hal ini terjadi karena pemerintah gagal dalam menjalankan perannya untuk menyediakan public goods, menetapkan regulasi yang tepat untuk mewujudkan pasar yang efisien dan memperbaiki kegagalan pasar. Oleh sebab itu, pemerintah perlu menerapkan good governance yaitu tata kelola pemerintahan yang baik yang didukung dengan adanya sistem akuntabilitas, informasi yang memadai dan dapat diandalkan, dan efisiensi dalam pengelolaan sumber daya dan penyelenggaraan pelayanan publik (The World Bank, 1992).

Untuk meningkatkan pertumbuhan ekonomi dan mewujudkan kesejahteraan masyarakat, sebuah negara membutuhkan sinergi yang baik di antara ketiga pilar good governance yang meliputi pemerintah, swasta, dan masyarakat. Pemerintah berperan penting dalam membuat kebijakan, mengawasi dan menjaga kestabilan dan kesinambungan ekonomi. Swasta berperan sebagai penggerak aktivitas ekonomi dan penciptaan lapangan kerja. Sedangkan masyarakat berpartisipasi dalam aktivitas ekonomi dan pengambilan kebijakan pemerintah dengan menjalankan peran masing-masing baik secara individu maupun kelompok (UNDP, 1997).

Sinergi yang kuat antara pemerintah, swasta, dan masyarakat dalam perumusan kebijakan publik merupakan elemen inti dari good governance. Melalui sinergi, pemerintah akan mendapatkan input berupa informasi yang lebih luas, gagasangagasan yang relevan dan dukungan sumber daya dalam merumuskan suatu kebijakan. Dengan demikian, kebijakan yang dihasilkan merupakan kebijakan yang menjadi konsensus antara pemerintah, swasta dan masyarakat sehingga mampu menghasilkan output, outcome dan benefit yang memenuhi harapan stakeholder (OECD, 2002).

Partisipasi masyarakat dapat dilakukan dengan baik apabila masyarakat memiliki akses yang mudah terhadap informasi yang relevan, andal, lengkap dan objektif. Oleh sebab itu, transparansi dan akuntabilitas menjadi faktor kunci untuk meningkatkan partisipasi masyarakat dalam pengambilan keputusan (OECD, 2002).

Pemerintah Indonesia telah berupaya untuk mendorong terwujudnya transparansi (open government) dengan menerbitkan Undang-Undang Nomor 14 Tahun 2008 tentang Keterbukaan Informasi Publik. Dalam Undang-Undang tersebut, ditegaskan bahwa setiap orang pada dasarnya berhak memperoleh informasi publik sesuai dengan ketentuan Undang-Undang. Setiap badan publik diwajibkan untuk memenuhi permintaan informasi publik selama informasi yang diminta bukan merupakan informasi yang dapat membahayakan negara, informasi yang berkaitan dengan kepentingan perlindungan usaha dan informasi sensitif lainnya. Badan Publik adalah lembaga eksekutif, legislatif, yudikatif, dan badan lain yang sebagian atau seluruh dananya bersumber dari Anggaran Pendapatan dan Belanja Negara (APBN), Anggaran Pendapatan dan Belanja Daerah (APBD), sumbangan masyarakat, atau hibah luar negeri. Dalam Undang-Undang tersebut badan publik wajib menyediakan dan menerbitkan informasi publik yang berada di bawah kewenangannya secara akurat, benar, dan tidak menyesatkan. Informasi yang disediakan terdiri dari informasi yang wajib disediakan secara berkala seperti laporan keuangan dan laporan kinerja, informasi yang wajib disediakan secara serta merta yang biasanya berkaitan dengan hajat hidup orang banyak dan informasi yang wajib tersedia setiap saat seperti struktur, profil, tugas dan fungsi organisasi. Umumnya, setiap Kementerian/Lembaga akan menyediakan informasi-informasi tersebut dalam website resminya masing-masing (Pemerintah Republik Indonesia, 2008).

Namun demikian, dari hasil Monitoring dan Evaluasi Keterbukaan Informasi Badan Publik Tahun 2018 yang dilakukan oleh Pemerintah Indonesia, dari 460 badan publik yang masuk kedalam sampel evaluasi, hanya $15(3,26 \%)$ badan publik yang mendapatkan kategori penilaian "informatif", $36(7,83 \%)$ badan publik "menuju informatif", 53 (11,52\%) badan publik "cukup informatif", $53(11,52 \%)$ badan publik "kurang informatif" dan 303 (65,87\%) badan publik "tidak informatif" (Komisi Informasi Pusat RI, 2018). Rendahnya tingkat transparansi dan akuntabilitas dari badan publik ini dapat mempengaruhi tingkat partisipasi masyarakat dalam pengambilan keputusan pemerintah. Hal ini selaras dengan data Indeks Demokrasi Indonesia yang dilansir oleh Badan Pusat Statistik (BPS) dimana variabel Partisipasi Politik dalam Pengambilan Keputusan dan Pengawasan Pemerintahan tahun 2018 yang hanya mendapatkan nilai 54,28 , turun 1,88 poin jika dibandingkan dengan capaian tahun 2017 dengan nilai 56,16. Nilai tersebut termasuk dalam kategori "buruk" karena untuk masuk dalam kategori 
"sedang", nilai minimal yang dibutuhkan adalah 60 dan untuk masuk dalam kategori "baik" nilai minimal yang dibutuhkan adalah 80 (Badan Pusat Statistik, 2019).

Pemerintah Indonesia telah merintis perbaikan tata kelola pemerintahan sejak tahun 2008, di mana saat itu terjadi krisis moneter dan masyarakat menuntut adanya reformasi sistem demokrasi dan pemerintahan yang bersih dari korupsi, kolusi, dan nepotisme (Maksudi, 2017). Pada tahun 1999, Pemerintah Indonesia membentuk Komite Nasional Kebijakan Governance (KNKG) sebagai salah satu implementasi Letter of Intent IMF (KNKG, 2019). KNKG berhasil menyusun Pedoman Umum Good Corporate Governance (GCG) Indonesia pada tahun 1999 yang kemudian disempurnakan pada tahun 2006. Pedoman Umum GCG diharapkan dapat menjadi rujukan bagi dunia usaha dalam menerapkan GCG perusahaan khususnya terkait interaksi di antara direksi, komisaris, internal perusahaan, pemegang saham, dan stakeholder lainnya (KNKG, 2006).

Sejak diterbitkannya Pedoman Umum GCG tersebut, good corporate governance di dunia usaha dirasakan mengalami peningkatan. Namun hal ini belum cukup, karena perbaikan good governance di sektor publik juga sangat penting dilakukan untuk meningkatkan daya saing Indonesia. Oleh sebab itu, pada tahun 2008, KNKG menerbitkan Pedoman bisnis masing-masing. Setiap lembaga negara harus melakukan internalisasi pelaksanaan GPG dengan harapan pelaksanaan GPG bukan hanya di atas kertas saja namun menjadi bagian budaya yang melekat dalam kegiatan sehari-hari. Selain itu, setiap lembaga negara juga dianjurkan untuk melakukan penilaian penerapan GPG secara berkesinambungan dan mengungkapkan hasil penilaian penerapan GPG tersebut dalam laporan tahunan yang dapat diakses oleh masyarakat luas (KNKG, 2008).

Baik di sektor privat maupun sektor publik, laporan tahunan dianggap sebagai sarana yang baik untuk mempertanggungjawabkan pengelolaan sumber daya kepada stakeholder dan mewujudkan akuntabilitas (Ryan, Dunstan, \& Brown, 2001, Cameron, 2004). Pada sektor privat di Indonesia, emiten dan perusahaan publik diwajibkan untuk menyusun laporan tahunan sebagai bentuk akuntabilitas perusahaan kepada stakeholder (Otoritas Jasa Keuangan, 2016). Laporan Tahunan wajib memuat beberapa informasi penting, diantaranya: ikhtisar data keuangan penting, informasi saham (jika ada), laporan Direksi, laporan Dewan Komisaris, laporan keuangan yang disusun sesuai Standard Akuntansi Keuangan (SAK) yang sudah diaudit dan tata kelola Emiten atau Perusahaan Publik (Otoritas Jasa Keuangan, 2016).

Dari 683 emiten yang terdaftar di Bursa Efek Indonesia, $681 \quad(99,71 \%)$ diantaranya telah

Tabel 1. Profil Publikasi Berbagai Laporan Kementerian/Lembaga Tahun 2018

\begin{tabular}{|c|c|c|c|c|c|c|}
\hline \multirow{2}{*}{ PROFIL } & \multicolumn{2}{c|}{ LAKIP } & \multicolumn{2}{c|}{ Laporan Keuangan } & \multicolumn{2}{c|}{ Laporan Tahunan } \\
\cline { 2 - 7 } & $\begin{array}{c}\text { Jumlah } \\
\text { K/L }\end{array}$ & $\mathbf{\%}$ & $\begin{array}{c}\text { Jumlah } \\
\text { K/L }\end{array}$ & $\%$ & $\begin{array}{c}\text { Jumlah } \\
\text { K/L }\end{array}$ & $\%$ \\
\hline $\begin{array}{c}\text { Menyusun dan menggunggah di } \\
\text { situs resmi }\end{array}$ & 69 & $80.23 \%$ & 48 & $55.81 \%$ & 19 & $22.09 \%$ \\
\hline $\begin{array}{l}\text { Tidak menyusun atau tidak } \\
\text { mengunggah di situs resmi }\end{array}$ & 17 & $19.77 \%$ & 38 & $44.19 \%$ & 67 & $77.91 \%$ \\
\hline \multicolumn{1}{|c|}{ Total } & $\mathbf{8 6}$ & $\mathbf{1 0 0 \%}$ & $\mathbf{8 6}$ & $\mathbf{1 0 0 \%}$ & $\mathbf{8 6}$ & $\mathbf{1 0 0 \%}$ \\
\hline
\end{tabular}

Sumber: diolah dari berbagai situs resmi Kementerian/Lembaga

Umum Good Public Governance (GPG) Indonesia atau yang lebih lanjut disebut dengan Pedoman Umum GPG Indonesia. Pedoman Umum GPG Indonesia memuat prinsip dasar dan pedoman pokok pelaksanaan yang berlaku bagi semua lembaga negara baik di ranah eksekutif, yudikatif, legislatif dan pengawasan maupun lembaga nonstruktural. Pedoman ini menyarankan setiap lembaga negara untuk menyusun panduan yang lebih operasional sesuai dengan stuktur dan proses menyusun Laporan Tahunan Perusahaan 2018 dan menyampaikannya kepada Otoritas Jasa Keuangan sehingga laporan tahunan tersebut dapat diakses dengan mudah di situs Bursa Efek Indonesia (Bursa Efek Indonesia, 2019). Dengan demikian, dapat dikatakan bahwa pelaksanaan akuntabilitas emiten dari sisi penyusunan dan penyampaian laporan tahunan telah dijalankan dengan baik.

Kondisi ini berbeda dengan fenomena yang terjadi pada sektor publik di Indonesia. Lembaga 
negara di Indonesia diwajibkan untuk menyusun Laporan Keuangan dan Laporan Kinerja Instansi Pemerintah (LAKIP). Laporan Keuangan disusun sesuai Standard Akuntansi Pemerintahan (SAP) dan memuat informasi keuangan yang terdiri dari Laporan Realisasi Anggaran, Neraca, Laporan Arus Kas, dan Catatan atas Laporan Keuangan. Sedangkan LAKIP memuat ringkasan tentang keluaran dari masing-masing kegiatan dan hasil yang dicapai dari setiap program yang dijalankan oleh suatu lembaga negara. LAKIP tidak memuat informasi tentang tata kelola lembaga negara (Pemerintah Republik Indonesia, 2006).

Berdasarkan penelusuran pada situs resmi
lembaga negara yang Kementerian/Lembaga Negara (K/L) di Indonesia sebagaimana pada tabel 1, ditemukan fakta bahwa publikasi LAKIP K/L sudah cukup baik di mana dari $86 \mathrm{~K} / \mathrm{L}, 69 \mathrm{~K} / \mathrm{L}$ (80,23\%) diantaranya sudah menyusun LAKIP dan menggunggahnya pada situs resmi masing-masing. Sementara itu publikasi laporan keuangan kurang baik dimana hanya 48 $\mathrm{K} / \mathrm{L}(55,81 \%)$ yang mengunggahnya pada situs resmi K/L. Meskipun bukan merupakan laporan yang mandatory bagi $\mathrm{K} / \mathrm{L}$, terdapat $19 \mathrm{~K} / \mathrm{L}$ $(22,08 \%)$ yang sudah berinisiatif (menjadi volunteer) untuk menyusun laporan tahunan dan mengunggahnya di situs resmi K/L. Dari $19 \mathrm{~K} / \mathrm{L}$ yang menyusun dan menggunggah laporan tahunan di situs resmi, hanya $11 \mathrm{~K} / \mathrm{L}$ yang mempublikasikan laporan tahunan secara terkini dengan mengunggah laporan tahunan 2018, $5 \mathrm{~K} / \mathrm{L}$ diantaranya mempublikasikan laporan tahunan 2017, 2 K/L diantaranya mempublikasikan laporan tahunan 2016 dan 1 K/L diantaranya mempublikasikan laporan tahunan 2015. Selain itu, struktur penyajian informasi dalam laporan tahunan dari masingmasing $\mathrm{K} / \mathrm{L}$ juga sangat beragam yang menunjukkan belum adanya standard dan pedoman dalam penyusunan laporan tahunan.

Fenomena sedikitnya K/L yang menyusun laporan tahunan ini, menunjukkan adanya keengganan dari K/L untuk menyusun dan mempublikasikan laporan tahunan. Keengganan ini menyebabkan tidak terpenuhinya hak masyarakat terhadap ketersediaan akses informasi penting tentang $\mathrm{K} / \mathrm{L}$, diantaranya informasi tentang proses bisnis/tata kelola, pertimbangan dalam pengambilan kebijakan, dampak dan manfaat dari program dan kegiatan, pandangan ke depan terkait situasi global dan nasional, dan langkah antisipatif dalam menghadapi peluang dan tantangan di masa yang akan datang. Lebih lanjut, keengganan ini menyebabkan kurangnya informasi yang diperoleh masyarakat yang kemudian menjadi salah satu faktor yang mengakibatkan variabel Partisipasi Politik dalam Pengambilan Keputusan dan Pengawasan Pemerintahan Indonesia dalam Indeks
Demokrasi Indonesia 2018 yang dirilis oleh BPS masih berada dalam kategori "buruk".

Fenomena dan faktor-faktor yang menjadi penyebab keengganan Kementerian/Lembaga Negara dalam menyusun dan mempublikasikan laporan tahunan yang bersifat non-mandatory dan berisi tentang informasi non-finansial, dapat digali lebih dalam melalui penelitian yang berlandaskan institutional theory. Institutional theory merupakan teori yang menjelaskan fenomena kecenderungan perubahan dalam organisasi menuju kesamaan (homogeneous) (DiMaggio \& Powell, 1983). Institutional theory terbagi ke dalam dua kelompok yaitu old institutional theory (OIT) dan new institutional theory (NIT). OIT memandang institutionalization terjadi karena adanya nilai (values), norma (norms) dan perilaku (attitudes) yang bersifat taken-for-granted, sedangkan NIT memandang institutionalization terjadi karena organisasi berfikir secara logis dengan mempertimbangkan classifications, routines, scripts, dan schema (Powell \& DiMaggio, 1991).

Ryan dan Ng (2000) menemukan fakta bahwa di Queensland, dislosure GPG untuk prinsip monitoring mendapat perhatian paling banyak dari badan publik karena mekanisme internal control telah diatur secara jelas oleh Queensland Treasury dan diawasi oleh ANAO. Sedangkan prinsip akuntabilitas mendapatkan perhatian yang paling sedikit karena sifatnya yang kompleks dan berpotensi menjadi "alat" bagi parlemen untuk mengkritisi pemerintah apabila diungkapkan. Meskipun tidak menggunakan institutional theory, temuan ini menjelaskan adanya coercive isomorphism atau pertimbangan logis atas adanya suatu tekanan politis dalam disclosure laporan tahunan.

Ryan, Dunstan, dan Brown (2002) menemukan fakta bahwa lembaga publik akan menyesuaikan tingkat disclosure laporan tahunan mereka dengan faktor tekanan dari luar yaitu kebutuhan dan permintaan dari stakeholder. Fenomena ini menjelaskan adanya normative isomorphism dalam penyusunan laporan tahunan.

Ntim, Soobaroyen, dan Broad (2017) menemukan fakta bahwa voluntary disclosures pada laporan tahunan Lembaga Pendidikan Tinggi di UK masih rendah dan sangat dipengaruhi oleh kualitas dari komite audit, keragaman latar belakang governing board, independensi governor dan keberadaan komite tata kelola. Meskipun tidak menggunakan institutional theory dalam penelitiannya, temuan dari Ntim et al. (2017) tersebut menjelaskan adanya pengaruh dari dua faktor material carriers yaitu actors, dan rules.

Dari studi penelitian terdahulu di atas, dapat disimpulkan bahwa penelitian terhadap motivasi pengungkapan informasi non-finansial dalam 
laporan tahunan badan publik masih belum dilakukan dengan menggunakan NIT dengan mengkombinasikan institutional logic dan isomorphism secara bersamaan. Sehingga, aplikasinya belum didapatan secara menyeluruh mengenai symbolic carriers, material carriers, dan isomorphism. Symbolic carriers terdiri dari aturan, norma, dan sistem kepercayaan yang tertanam dalam institutional logics, sedangkan material carriers adalah routines, relationship systems, dan artifacts yang muncul dan membentuk institutional logics (Lepoutre \& Valente, 2012). Menurut DiMaggio dan Powell (1983) isomorphic change merupakan mekanisme perubahan organisasi menuju kearah yang sama (homogenization) karena adanya pengaruh dari luar.

Penelitian ini berupaya untuk mengisi research gap tersebut dengan menggunakan pendekatan NIT mengombinasikan institutional logic dan isomorphism agar didapatkan gambaran fenomena secara lebih lengkap tentang fenomena dan faktorfaktor yang mempengaruhi tingkat pengungkapan informasi non-finansial dalam laporan tahunan badan publik. Selain itu, karena belum adanya standard dan pedoman dalam penyusunan laporan tahunan di Indonesia, diperlukan penelitian yang dapat memberikan masukan mengenai struktur dan sistematika penyajian informasi pada laporan tahunan yang baik.

Berdasarkan pertimbangan latar belakang dan permasalahan di atas, terdapat beberapa pertanyaan yang perlu dijawab dengan adanya penelitian ini, yaitu:

1. Bagaimana dengan tingkat kesamaan $\mathrm{K} / \mathrm{L}$ dalam penyusunan dan publikasi Laporan Tahunan?

2. Apakah ada logika dominan yang menyeluruh (an overarching dominant logic)? Secara rinci, pertanyaan ini ditetapkan untuk menjawab:

a. Sejauh mana K/L dalam melakukan penyusunan dan publikasi Laporan Tahunan menerapkan dan memenuhi semua persyaratan pembawa simbolik (symbolic carriers)?

b. Sejauh mana pengaruh faktor lokal terhadap praktik penyusunan dan publikasi Laporan Tahunan di K/L?

c. Apakah ada satu atau beberapa logika terhadap praktik penyusunan dan publikasi Laporan Tahunan di K/L?

3. Bagaimana dengan faktor institusional yang memfasilitasi atau mencegah praktik pembawa materi (material carriers) dipisahkan dari pembawa simbolik (symbolic carriers)?

4. Bagaimana dengan tingkat kesamaan $\mathrm{K} / \mathrm{L}$ lainnya atas tekanan-tekanan isomorfis baik yang berasal dari dalam maupun luar institusi (mimetic isomorphism, coercive isomorphism, atau normative isomporphism)?

Penelitian ini bertujuan untuk menutup research gap di mana penelitian terhadap motivasi penyusunan laporan tahunan dan pengungkapan informasi non-finansial masih menggunakan pendekatan NIT yang bersifat parsial sehingga perlu dilakukan penelitian dengan pendekatan NIT yang mengkombinasikan institutional logics dan isomorphism secara bersamaan. Selain itu, terdapat beberapa tujuan khusus yang ingin dicapai oleh penelitian ini, yaitu:

1. Mengidentifikasi dan menganalisis persamaan dan perbedaan logika dan motivasi lembaga negara dalam penyusunan dan publikasi laporan tahunan.

2. Merumuskan upaya yang dapat dilakukan oleh lembaga negara untuk meningkatkan motivasi penyusunan dan publikasi laporan tahunan.

\section{LANDASAN TEORI}

Bagian ini menjelaskan tentang institutional theory yang menjadi landasan penelitian. Selanjutnya dibahas pula mengenai dua dimensi dari institutional theory yaitu institutional logics dan isomorphism. Institutional logics digunakan untuk menganalisis perilaku individu terkait dengan perspektif dan motivasi yang terbentuk dipengaruhi oleh symbolic carriers dan material carriers. Sedangkan melalui pendekatan isomorphism, digunakan untuk mendeteksi fenomena perubahan organisasi menuju homogenisasi ke arah yang dianggap lebih baik berupa coercive isomorphism, mimetic isomorphism, dan normative isomorphism. Selain itu, bagian ini juga menyampaikan tentang penelitian terdahulu beserta research gap-nya dan kerangka teoritis penelitian.

\subsection{Teori Institusional (Institutional Theory)}

Institutional theory merupakan salah satu teori yang banyak dipakai untuk memahami perilaku individu dan organisasi (Dacin, Goodstein, \& Scott, 2002). Teori ini awalnya menjelaskan bagaimana struktur makna yang dilembagakan mempengaruhi proses dalam organisasi (Greenwood \& Suddaby, 2006). Dalam perkembangannya, institutional theory terbagi dalam 2 kelompok pandangan yaitu old-instituonal theory (OIT) dan new institutional theory (NIT). OIT berpendapat bahwa institutionalization terjadi karena adanya nilai (values), norma (norms) dan perilaku (attitudes) yang bersifat taken-for-granted, sedangkan NIT berpendapat bahwa institutionalization terjadi karena organisasi berfikir secara logis dengan mempertimbangkan classifications, routines, scripts, schema (Powell \& DiMaggio, 1991). 
Pendekatan OIT tidak dapat digunakan dalam penelitian ini karena berpandangan bahwa perilaku organisasi dipengaruhi faktor-faktor yang sudah given, sedangkan pada kenyataannya, dinamika organisasi semakin kompleks (DiMaggio \& Powell, 1983) dan actors memiliki pemikiran logis yang dapat menjadi awal dari perubahan dalam organisasi (Reay \& Hinings, 2009). Oleh sebab itu, penelitian ini menggunakan pendekatan NIT berupa konsep isomorphism yang dikembangkan oleh DiMaggio \& Powell (1983) dan institutional logics yang dikembangkan oleh Friedland \& Alford (1991), Thornton, Ocasio, \& Lounsbury (2012) dan Zilber (2013).

Dalam kaitannya dengan penyusunan dan publikasi laporan tahunan sektor publik, para aktor yang dalam hal ini adalah para penyusun laporan tahunan di lingkungan K/L sebenarnya berada dalam satu lingkungan peraturan yang sama. Namun praktik penyusunan dan publikasi laporan tahunan ini kemudian menjadi berbeda karena masing-masing aktor memiliki logika yang berbeda yang dipengaruhi oleh classifications, routines, scripts, schema di lingkungan K/L masing-masing. Selain itu, perbedaan logika aktor mungkin dipengaruhi pula oleh faktor-faktor dari luar seperti tekanan politik dari lembaga tertentu, keputusan yang diambil oleh aktor lain dan tuntutan profesionalisme dari stakeholder.

\subsection{Logika Institusional (Institutional Logics)}

Perspektif Institutional Logics adalah sebuah kerangka metateoritis yang mempelajari hubungan timbal balik antara lembaga, individu dan organisasi dalam tatanan sosial (Thornton et al., 2012). Institutional logics mempelajari konstruksi sosial, pola historis dari praktik-praktik material, asumsi, nilai-nilai, kepercayaan, dan aturan-aturan yang digunakan oleh individu dalam menghasilkan nafkah hidup, mengatur ruang dan waktu, dan memberikan makna pada realitas sosial mereka (Thornton \& Ocasio, 1999). Institutional logics juga mewakili kerangka referensi yang mempengaruhi aktor untuk membuat pilihan yang logis, merumuskan kata untuk memotivasi tindakan, perasaan diri dan identitas mereka (Thornton et al., 2012). Institutional logics merupakan pendekatan yang tepat untuk mendapatkan pandangan yang holistik dan koheren mengenai bagaimana organisasi disusun dan dikelola (Greenwood, Hinings, \& Whetten, 2014).

Terdapat 4 prinsip utama dalam perspektif institutional logics, yaitu: (1) terintegrasinya lembaga dan struktur; (2) terintegrasinya materi dengan simbolik; (3) memperhatikan kontinjensi historis dari lembaga; dan (4) memperhatikan institusi seluruh tingkatan sosial (Zilber, 2013). Prinsip yang paling utama dalam institutional logics adalah terintergrasinya aspek material (material aspects) dan aspek simbolik (symbolic aspects) dan ini adalah prinsip yang membedakan NIT dengan OIT (Thornton et al., 2012). Symbolic aspects merujuk pada proses ideasi dan makna, sedangkan material aspects merujuk pada struktur dan praktik dalam organisasi (Thornton et al., 2012).

Symbolic carriers terdiri dari aturan, norma, dan sistem kepercayaan yang tertanam dalam institutional logics (Lepoutre \& Valente, 2012). Dalam kaitannya dengan penyusunan dan publikasi laporan tahunan sektor publik, symbolic carriers dapat terdiri dari peraturan atau pedoman yang berlaku secara internasional maupun nasional. Di tingkat internasional terdapat beberapa pedoman yang mungkin dapat mempengaruhi logika dari actors, yaitu:

1. Publikasi Organisation for Economic CoOperation and Development (OECD) pada tahun 2002 yang berjudul Public Sector Transparency and Accountability menyebutkan bahwa salah satu area utama dalam good governance adalah meningkatkan keterbukaan informasi, konsultasi dan partisipasi masyarakat dalam perumusan dan pelaksanaan kebijakan publik. Salah satu alat yang dapat digunakan pemerintah untuk aktif menyediakan informasi adalah laporan tahunan yang memuat informasi keuangan dan non-keuangan seperti perbandingan antara target dan capaian kinerja (OECD, 2002).

2. International Framework: Good Governance in The Public Sector yang dirumuskan oleh Chartered Institute of Public Finance and Accountancy (CIPFA) dan International Federation of Accountants (IFAC) pada tahun 2014. Sebagai bentuk akuntabilitas dalam penggunaan sumber daya publik, pemerintah harus menyusun laporan tahunan. Laporan tahunan harus dilengkapi dengan informasi kinerja dan informasi tentang penilaian prinsip tata kelola pemerintahan yang baik termasuk rencana aksi untuk perbaikan tata kelola dimaksud (IFAC \& CIPFA, 2014). Selain tu, Laporan tahunan juga harus dilengkapi informasi tentang penerapan manajemen risiko dan pengendalian internal (OPM \& CIPFA, 2004).

3. Pedoman Penyusunan Laporan Tahunan oleh negara maju seperti Australia dan United Kingdom (UK). Pemerintah Australia mewajibkan setiap lembaga publik untuk menyusun laporan tahunan melalui Financial Accountability Act yang disahkan pada tahun 2009. Peraturan tersebut kemudian dilengkapi dengan beberapa pedoman teknis diantaranya Model Annual Reports yang dikeluarkan oleh Departemen of Treasury, Annual Report Checklist yang dikeluarkan oleh Public Sector Commission (PSC) serta Good Practice in Annual 
Report 2017-2018 yang dikeluarkan oleh National Audit Office (NAO). Sedangkan di UK, HM Treasury mengeluarkan The Government Financial Reporting Manual (GFReM) untuk setiap tahun anggaran.

Di tingkat nasional, terdapat beberapa pedoman atau peraturan yang mungkin dapat menjadi pertimbangan dari aktor dalam mengambil keputusan untuk menyusun atau tidak menyusun dan mempublikasikan atau tidak mempublikasikan laporan tahunan, yaitu sebagai berikut:

1. Pedoman Good Public Governance yang dirumuskan oleh Komite Nasional Kebijakan Governance (KNKG);

2. Undang-Undang Nomor 1 Tahun 2004 tentang Perbendaharaan Negara;

3. Undang-Undang Nomor 14 Tahun 2008 tentang Keterbukaan Informasi Publik;

4. Peraturan Presiden Republik Indonesia Nomor 29 Tahun 2014 Tentang Sistem Akuntabilitas Kinerja Instansi Pemerintah;

5. Peraturan Pemerintah Republik Indonesia Nomor 8 Tahun 2006 Tentang Pelaporan Keuangan dan Kinerja Instansi Pemerintah; dan

6. Peraturan Menteri Pendayagunaan Aparatur Negara dan Reformasi Birokrasi Republik Indonesia Nomor 53 Tahun 2014 Tentang Petunjuk Teknis Perjanjian Kinerja, Pelaporan Kinerja dan Tata Cara Reviu Atas Laporan Kinerja Instansi Pemerintah.

Material carriers terdiri dari 3 hal yaitu relational systems, routines dan artifacts (Scott, 1995). Relational systems merupakan interaksi dan hubungan antar aktor baik dalam satu organisasi maupun lintas organisasi. Relational systems merupakan aspek yang paling banyak menimbulkan difusi atau persebaran budaya, teknologi atau ide dari satu pihak ke pihak lainnya. Relational systems akan semakin kuat ketika terbentuk community of practices atau suatu wadah yang memungkinkan terjadinya diskusi dan pertukaran ide antar aktor (Scott, 2003). Dalam kaitannya dengan penyusunan dan publikasi laporan tahunan sektor publik, relational systems dapat terjadi di lingkup internal suatu K/L yakni antar individu, bidang/bagian, dan eselon. Selain itu, relational systems juga dapat terbentuk dari interaksi aktor (PPID) antar K/L.

Logika aktor juga dapat dipengaruhi oleh routines yang terbentuk dalam organisasi. Routines merupakan kebiasaan yang menjadi budaya organisasi atau aktivitas-aktivitas yang berpola yang mencerminkan pengetahuan dan pemahaman (tacit knowledge) dari aktor (Scott, 2003). Dalam penyusunan dan publikasi laporan tahunan sektor publik, routines dapat merujuk pada standard operating procedures (SOP) dan budaya organisasi yang mempengaruhi logika aktor dalam mengambil keputusan.

Material carriers yang ketiga adalah artifacts yang merujuk pada budaya material yang diciptakan oleh kecerdasan manusia yang dikembangkan untuk membantu pelaksanaan tugas (Scott, 2003). Dalam penyusunan dan publikasi laporan tahunan sektor publik, artifacts dapat berupa sistem informasi, dukungan teknologi, kegiatan asistensi dan dukungan teknis lainnya.

\subsection{Isomorphism}

Organisasi bukan hanya berkompetisi untuk memperoleh sumber daya dan customer, akan tetapi lebih dari itu, organisasi juga berkompetisi untuk mendapatkan kekuatan politik, legitimasi institusi dan untuk kepentingan sosial (DiMaggio \& Powell, 1983). Oleh sebab itu, DiMaggio dan Powell (1983) memperkenalkan isomorphic change yaitu perubahan organisasi menuju kearah yang sama (homogenization) karena adanya pengaruh dari luar. DiMaggio dan Powell (1983) mengidentifikasi terdapat 3 mekanisme terjadinya isomorphic change yaitu coercive isomorphism, normative isomorphism, dan mimetic isomorphism.

Coercive isomorphism ditimbulkan karena adanya pengaruh politik dan permasalahan legitimasi dari luar organisasi (DiMaggio \& Powell, 1983). Coercive isomorphism dapat datang dari organisasi yang berperan sebagai regulator (Thornton et al., 2012). Sebagai organisasi yang bergerak pada sektor publik, aktor yang bertugas untuk menyusun dan mempublikasikan laporan tahunan tentunya tidak dapat lepas dari pengaruh lembaga regulator. Oleh sebab itu, coercive isormphism sangat mungkin terjadi pada proses penyusunan dan publikasi laporan tahunan.

Normative isomorphism suatu mekanisme perubahan dalam organisasi yang dipicu adanya dorongan profesionalisme (DiMaggio \& Powell, 1983). Lebih lanjut, DiMaggio dan Powell (1983) menjelaskan bahwa dorongan profesionalisme ini dapat berasal dari tuntutan stakeholder maupun dari kesepakatan organisasi profesi. Organisasi sektor publik seperti K/L tentu memiliki banyak sekali stakeholder. Dengan semakin berkembangnya dinamika sosial, sangat mungkin K/L dihadapkan pada tuntutan dari stakeholder agar semakin profesional dalam berkinerja. Fenomena tersebut secara logis juga sangat mungkin terjadi dalam proses penyusunan dan publikasi laporan tahunan sektor publik.

Mimetic isomorphism merupakan suatu perubahan organisasi karena adanya ketidakpastian dalam konteks tertentu. Saat menghadapi ketidakpastian atau tidak ada suatu standard yang jelas yang harus dijalankan, organisasi akan cenderung melihat organisasi 
lainnya (melakukan benchmarking) dan akan meniru organisasi lain dalam suatu aspek yang dianggap baik apabila diterapkan di organisasi (DiMaggio \& Powell, 1983). Dalam kaitannya dengan penyusunan dan publikasi laporan tahunan, mimetic isomorphism mungkin terjadi karena hingga saat ini belum terdapat suatu peraturan khusus yang mewajibkan K/L untuk menyusun laporan tahunan termasuk standard yang harus dipedomani dalam penyusunannya.

\subsection{Penelitian Terdahulu}

Dari penelitian tentang pengungkapan informasi corporate governance pada laporan tahunan sektor publik di Queensland ditemukan fakta bahwa dari kelima prinsip corporate governance yang dirumuskan oleh Australian National Audit Office (ANAO), prinsip monitoring mendapatkan perhatian paling banyak dan diungkapkan oleh $83,33 \%$ badan publik yang menjadi sampel penelitian, selanjutnya berturutturut prinsip manajemen risiko $72.22 \%$, prinsip lingkungan manajemen 61,11\%, prinsip kepemimpinan 55,56\% dan prinsip akuntabilitas 27,78\%. Prinsip monitoring mendapatkan perhatian paling banyak dari badan publik karena mekanisme internal control telah diatur secara jelas oleh Queensland Treasury dan diawasi oleh ANAO. Sedangkan prinsip akuntabilitas mendapatkan perhatian yang paling sedikit karena sifatnya yang kompleks dan berpotensi menjadi "alat" bagi parlemen untuk mengkritisi pemerintah apabila diungkapkan (Ryan \& Ng, 2000). Dari dari sudut pandang institutional theory, temuan tersebut menjelaskan adanya coercive isomorphism dan logika dari actors sedangkan aspek-aspek lain seperti mimetic dan normative isomorphism belum terjawab dari penelitian ini. Hal ini terjadi karena Ryan dan Ng (2000) tidak menggunakan pendekatan institutional theory dalam penelitiannya.

Dari sumber yang lain, ditemukan fakta bahwa perbedaan stakeholder dari badan-badan publik di Australia mempengaruhi tingkat disclosure laporan tahunan masing-masing badan publik. Badan publik akan menyesuaikan tingkat disclosure laporan tahunan mereka dengan faktor tekanan dari luar yaitu kebutuhan dan permintaan dari stakeholder. Jadi bukan hanya sekedar faktor coercive isomorphism dari adanya peraturan yang mewajibkan penyusunan laporan tahunan yang mempengaruhi tingkat disclosure dari laporan tahunan akan tetapi terdapat faktor luar lainnya yaitu tuntutan dari stakeholder yang merupakan normative isomorphism (Ryan et al., 2002). Penelitian Ryan et al. (2002) hanya meneliti pengaruh dari perbedaan stakeholder terhadap praktek dan kebijakan yang diadopsi oleh organisasi dalam menyusun laporan tahunan sehingga kita belum mendapatkan gambaran yang utuh tentang adanya isomorphism dan institutional logics.

Ntim et al. (2017) menemukan fakta bahwa tingkat voluntary disclosures pada laporan tahunan Lembaga Pendidikan Tinggi di UK masih rendah dan dipengaruhi oleh kualitas dari komite audit, keragaman latar belakang governing board, independensi governor dan keberadaan komite tata kelola. Jika di lihat dari sudut pandang institutional theory, temuan tersebut hanya menjelaskan adanya pengaruh dari dua faktor material carriers yaitu actors, dan rules. Sedangkan symbolic carriers, isomorphism dan 2 faktor material carriers lainnya yaitu artifacts dan routines belum dijelaskan. Tingkat voluntary disclosures dalam laporan tahunan yang rendah ini memang serupa dengan yang terjadi pada K/L di Indonesia, namun faktorfaktor yang menjadi penyebabnya perlu digali lebih dalam dengan menggunakan institutional theory untuk kemudian dirumuskan solusi yang lebih applicable.

\subsection{Kerangka Teoritis Penelitian}

Kerangka teoritis penelitian adalah struktur keterkaitan antar teori dan perspektif yang berpengaruh baik secara langsung ataupun tidak langsung terhadap suatu penelitian yang dilakukan. Kerangka teoritis penelitian ini penting untuk disusun agar peneliti dapat fokus dalam melakukan studi literatur yaitu dengan membaca dan memahami teori dan perspektif yang terkait dengan penelitian saja (Kumar, 2011). Dari studi literatur yang telah dipaparkan pada subbagian 2.1. s.d. 2.4., kerangka teoritis penelitian dapat kita gambarkan sebagaimana Gambar 1.

Keputusan para aktor yang terlibat dalam proses penyusunan dan publikasi laporan tahunan, pada dasarnya dipengaruhi oleh institutional logics dan isomorphism. institutional logics terdiri dari symbolic carriers dan material carriers. Symbolic carriers berupa peraturan dan pedoman transparansi dan akuntabilitas sektor publik baik di tingkat internasional maupun nasional. Material carriers terdiri dari 3 aspek yaitu relational systems, routines dan artifacts. Relational systems dapat terbentuk karena adanya interaksi di lingkup internal suatu K/L yakni antar individu, 


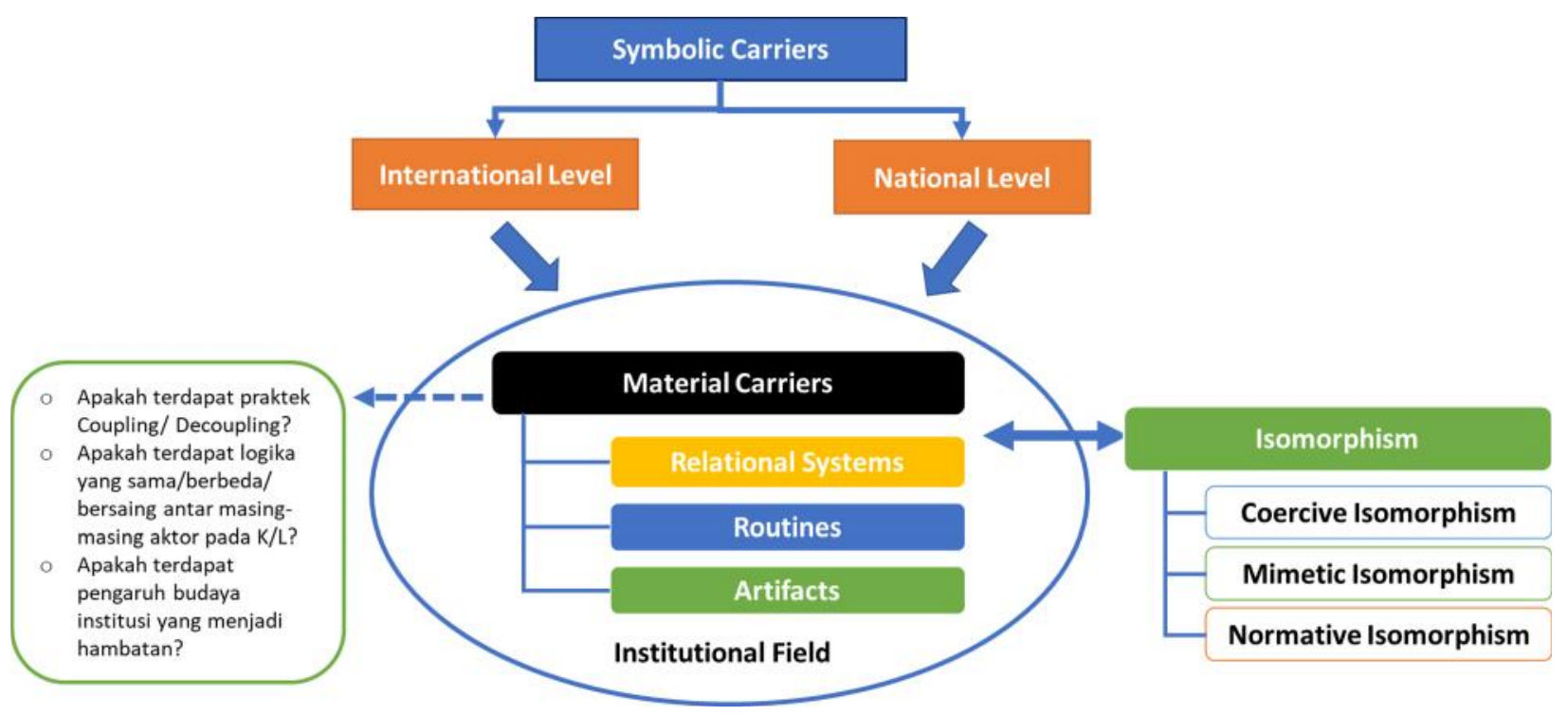

Sumber: DiMaggio \& Powell (1983), Thornton et al. (2012) dan Zilber (2013), telah diolah kembali.

bidang/bagian dan eselon. Selain itu, relational systems juga dapat terbentuk dari interaksi aktor (PPID) antar K/L. Routines dapat berupa standard operating procedures (SOP) dan budaya organisasi yang mempengaruhi logika aktor dalam mengambil keputusan. Sedangkan artifacts berupa sistem informasi, dukungan teknologi, kegiatan asistensi dan dukungan teknis lainnya.

Isomorphism terdiri dari 3 jenis yaitu coercive isomorphism, normative isomorphism, dan mimetic isomorphism. Coercive isomorphism berupa pengaruh lembaga regulator sangat mungkin terjadi pada proses penyusunan dan publikasi laporan tahunan. Normative isomorphism dapat terjadi karena adanya tuntutan stakeholder maupun dari kesepakatan organisasi profesi. Sedangkan mimetic isomorphism dapat terjadi karena keputusan aktor dipengaruhi oleh keputusan aktor lainnya sebab adanya suatu ketidakpastian.

\section{METODOLOGI PENELITIAN}

Bagian ini membahas mengenai strategi dan pendekatan penelitian, metode pengumpulan data, dan teknik analisis data yang digunakan untuk menjawab pertanyaan penelitian sebagaimana yang disebutkan pada subbagian 1.2 di atas. Selain itu juga memaparkan gambaran umum dari unit analisis yang menjadi objek penelitian.

\subsection{Strategi dan Pendekatan Penelitian}

Penelitian ini menggunakan pendekatan qualitative case study yaitu penelitian yang lebih menekankan pada informasi kualitatif dari suatu objek, kejadian ataupun aktivitas dalam suatu organisasi (Sekaran \& Bougie, 2016). Penelitian case study merupakan cabang dari penelitian kualitatif yang cocok digunakan untuk menggali fenomena dan permasalahan dalam situasi real-life dari berbagai sudut pandang dan perspektif dengan menggunakan multiple methods dalam pengumpulan data (Yin, 2009). Metode penelitian case study harus didasarkan pada suatu teori sehingga metode penelitian ini lebih tepat digunakan untuk menjawab pertanyaan penelitian yang bersifat mengapa dan bagaimana (Shauki, 2018).

Penelitian ini menggali fenomena penyusunan dan publikasi laporan tahunan sektor publik yang dilakukan oleh $\mathrm{K} / \mathrm{L}$ secara mendalam dengan menggunakan kerangka institutional theory untuk menjawab pertanyaan penelitian yang bersifat mengapa (why) dan bagaimana (how). Data-data yang dihimpun lebih bersifat kualitatif yang mencerminkan fenomena yang terjadi dalam situasi yang sebenarnya real-life. Kasus yang dianalisis bukan hanya terjadi pada satu K/L saja melainkan seluruh K/L di Indonesia sehingga penelitian ini dapat disebut pula penelitian multiple case study (Yin, 2009).

\subsection{Pengumpulan Data}

Teknik pengumpulan data yang digunakan dalam penelitian ini bersifat triangulation dengan menggunakan campuran data atau metode yang dapat menggambarkan posisi dan sudut pandang yang jelas terkait dari topik tertentu (Olsen dalam Shauki, 2018). Pada tahap awal, dilakukan penggalian data dan informasi yang berasal dari website resmi K/L untuk mendapatkan gambaran variasi praktek penyusunan dan publikasi laporan tahunan. Pada tahap kedua, dilakukan penyebaran kuesioner dengan open-ended questions yang terlebih dahulu divalidasi. Kemudian pada tahap 
yang ketiga, dilakukan wawancara yang bersifat semi-structured untuk memvalidasi data dan informasi yang diperoleh pada tahap pertama dan kedua.

Penggalian data sekunder dilakukan dengan mengunjungi website resmi yang dikelola oleh masing-masing K/L. Data sekunder yang didapatkan adalah profil dari masing-masing $\mathrm{K} / \mathrm{L}$ apakah mereka telah menyusun dan mempublikasikan laporan tahunan atau tidak. Selanjutnya untuk penggalian data primer, dikembangkan kuesioner open-ended questions berdasarkan kerangka teoritis penelitian dengan asistensi dari pembimbing. Surat ijin penelitian disertai dengan kuesioner dikirimkan melalui alamat surel PPID masing-masing K/L dan dikonfirmasi melalui telepon ke bidang/bagian terkait. Responden mengisi kuesioner secara online melalui googleform yang didesain oleh peneliti untuk mempercepat pengumpulan dan pengolahan data.

Selanjutnya hasil pengisian kuesioner dianalisis untuk dapat mengembangkan daftar pertanyaan wawancara yang bersifat semistructured. Wawancara ini berfungsi untuk memvalidasi data yang diperoleh pada tahap pertama dan tahap kedua serta menggali fenomena secara lebih mendalam yang mungkin tidak dapat dilakukan jika hanya menggunakan survey. Rekaman wawancara kemudian dirubah dalam bentuk transkrip berupa teks yang digunakan dalam tahap analisis data.

\subsection{Analisis Data}

Hasil survey dan transkrip wawancara dianalisis dengan menggunakan teknik content analysis, thematic analysis, dan constant comparative analysis dengan bantuan software NVIVO 12 Pro. Contenct analysis adalah teknik penelitian yang digunakan untuk melakukan analisis terhadap suatu teks atau hal lain yang mengandung makna untuk mendapatkan kesimpulan yang valid dan dapat direplika sesuai konteks penggunaannya (Krippendorff, 2004). Content analysis bertujuan untuk membuat kode dan mengelompokkan data ke dalam ukuran kuantitatif dalam rangka operasionalisasi konstruksi tertentu (Shauki, 2018). Melalui content analysis ini, peneliti mendapatkan topik-topik yang menjadi perhatian dari responden yang berguna untuk mengembangkan daftar pertanyaan semistructured interview.

Thematic analysis adalah metode untuk mengidentifikasi, menganalisis dan melaporkan pola (tema) dalam data. Dengan thematic analysis, peneliti dapat mengatur dan menjelaskan set data atau lebih dari itu, peneliti dapat menafsirkan berbagai aspek dan topik yang menjadi perhatian dari responden (Braun \& Clarke, 2006). Thematic analysis dilakukan untuk memahami skala dari respon, tema dan diskursus dari suatu corpus (kuantitas) data atau jawaban survey yang bersifat open-ended (Shauki, 2018). Menurut Braun dan Clarke (2006), terdapat 6 tahapan yang harus dilakukan dalam thematic analysis, yaitu:

1. Membiasakan diri dengan data yaitu dengan membaca secara berulang-ulang, dan mencatat ide awal.

2. Menghasilkan kode awal yaitu dengan mencari kode secara sistematis dari serangkaian data dan mengelompokkan data yang relevan untuk setiap kode.

3. Mencari tema yaitu dengan menterjemahkan kode menjadi tema potensial dan mengumpulkan semua data yang relevan dengan setiap tema potensial.

4. Meninjau tema yaitu dengan mempertimbangkan kembali apakah tema dapat berfungsi dan kemudian menyusun peta tematik analisis.

5. Menentukan dan menamai tema yaitu dengan melakukan analisis dan menyaring setiap tema untuk menghasilkan definisi dan nama yang jelas dari setiap tema.

6. Memproduksi laporan yaitu dengan menghubungkan kembali analisis dengan pertanyaan penelitian dan literatur kemudian merumuskan deskripsi yang jelas dan menarik untuk dituangkan dalam laporan ilmiah.

Selanjutnya dilakukan constant comparative analysis yang merupakan metode yang lebih komprehensif dari thematic analysis. Constant comparative analysis membandingkan tema yang dideskripsikan oleh kelompok responden satu dengan kelompok responden lainnya untuk mendapatkan gambaran mengenai persamaan, perbedaan, tren, dan konsistensi (Shauki, 2018). Lebih lanjut Shauki (2018) menyampaikan bahwa terdapat 5 langkah dalam constant comparative analysis, yaitu: perbandingan antar data tunggal, perbandingan hasil interview dalam satu grup yang sama, perbandingan interview dengan grup yang berbeda, perbandingan dalam satu pasangan unit, perbandingan antar pasangan unit dan perbandingan hasil antar instrumen penelitian.

\subsection{Unit Analisis}

Unit analisis merupakan sumber aktual dari informasi yang dapat berupa individu, organisasi, dokumen maupun artifacts (Shauki, 2018). Unit analisis dalam penelitian ini adalah para pejabat/staf yang berperan sebagai Pejabat Pengelola Informasi dan Dokumentasi di level pusat K/L. Jumlah PPID K/L yang menjadi target survey adalah $86 \mathrm{~K} / \mathrm{L}$ di Indonesia. Dari 86 target survey tersebut, peneliti memilih $10 \mathrm{~K} / \mathrm{L}$ yang dijadikan 
sebagai unit analysis dalam indepth-interview yang terdiri dari $5 \mathrm{~K} / \mathrm{L}$ yang menyusun dan mempublikasikan laporan tahunan dan $5 \mathrm{~K} / \mathrm{L}$ yang tidak menyusun dan mempublikasikan laporan tahunan.

\section{HASIL PENELITIAN}

Bagian ini membahas mengenai temuan penelitian serta analisis dan diskusi penelitian untuk menjawab beberapa pertanyaan penelitian yang telah disebutkan pada bagian 1 .

\subsection{Temuan Penelitian}

Pada tahap penyusunan dan penyebaran kuesioner, peneliti mengembangkan kuesioner yang terdiri dari 18 pertanyaan, yang terdiri dari 14 pertanyaan bersifat open-ended question dan 4 pertanyaan bersifat closed-ended question. Penyebaran kuesioner dilakukan dengan cara mengirimkan ke alamat surel PPID pada $86 \mathrm{~K} / \mathrm{L}$ yang menjadi unit analisis. Untuk meningkatkan response dari $\mathrm{K} / \mathrm{L}$ terhadap survey, peneliti melakukan konfirmasi lewat telepon dan mendatangi secara langsung ke beberapa K/L. Namun demikian, hingga batas waktu yang ditentukan, hanya $4 \mathrm{~K} / \mathrm{L}$ yang memberikan response kuesioner, sedangkan K/L lainnya masih terkendala dalam hal birokrasi.

Pada tahap wawancara (in-depht interview), peneliti mendatangi secara langsung ke $6 \mathrm{~K} / \mathrm{L}$ untuk menyerahkan surat permohonan wawancara. Selain itu, peneliti melakukan konfirmasi melalui telepon ke $6 \mathrm{~K} / \mathrm{L}$ tersebut. Namun demikian, hingga batas waktu yang ditentukan hanya $1 \mathrm{~K} / \mathrm{L}$ yang dapat mengalokasikan waktu untuk wawancara, sementara $5 \mathrm{~K} / \mathrm{L}$ lainnya masih dalam proses birokrasi.

Dari response kuesioner yang masuk, semua $\mathrm{K} / \mathrm{L}(100 \%)$ telah menyusun laporan keuangan dan mempublikasikannya melalui situs resmi K/L atau situs resmi PPID K/L. Data ini cocok dengan data yang diperoleh oleh peneliti dari penelusuran situs resmi K/L atau situs resmi PPID K/L. Terkait penyusunan dan publikasi LAKIP, seluruh K/L (100\%) mengaku telah menyusun dan mempublikasikan LAKIP, namun demikian dari penelusuran yang dilakukan, hanya tiga K/L (75\%) diantaranya telah menyusun dan mempublikasikan, sedangkan satu K/L (25\%) diantaranya tidak menyusun LAKIP. Terkait laporan tahunan, seluruh $\mathrm{K} / \mathrm{L} \quad(100 \%)$ menjawab bahwa mereka telah menyusun dan mempublikasikan laporan tahunan. Data ini berbeda dengan kondisi sebenarnya yang ditemukan melalui penelusuran di situs resmi K/L dan situs resmi PPID K/L, di mana dari $4 \mathrm{~K} / \mathrm{L}$ yang mengisi survey, hanya terdapat dua K/L (50\%) yang telah menyusun dan mempublikasikan laporan tahunan sedangkan dua K/L (50\%) tidak menyusun dan mempublikasikan laporan tahunan. Satu K/L yang berhasil diwawancara telah menyusun dan mempublikasikan semua laporan, baik itu laporan keuangan, LAKIP dan laporan tahunan.

Perbedaan antara jawaban kuesioner dengan kondisi yang ditemukan setelah melakukan penelusuran di situs resmi K/L dan situs resmi PPID $\mathrm{K} / \mathrm{L}$ ini menggambarkan adanya fenomena pemberian impresi positif yang ditunjukkan oleh K/L. Sebagaimana pendapat Vardi dan Weitz. (2004), responden mempunyai kecenderungan untuk membuat impresi yang positif mengenai mereka atau organisasi mereka sehingga mungkin terdapat distorsi pada data penelitian. Terkait dengan perbedaan data penyusunan dan publikasi laporan keuangan, LAKIP dan laporan tahunan ini, peneliti memposisikan data penelusuran melalui situs resmi K/L dan situs resmi PPID K/L lebih dapat diyakini dibandingkan dengan jawaban kuesioner yang diberikan oleh responden.

\subsection{Analisis dan Diskusi}

Untuk menjawab pertanyaan penelitian pertama, tentang tingkat kesamaan $\mathrm{K} / \mathrm{L}$ dalam penyusunan dan publikasi Laporan Tahunan, peneliti membaca laporan tahunan yang telah disusun oleh $\mathrm{K} / \mathrm{L}$ dan melakukan analisis konten untuk menentukan tema informasi yang diungkapkan pada laporan tahunan K/L beserta tingkat penyampaiannya (disclosure). Dari analisis ini, ditemukan bahwa terdapat 22 tema informasi yang telah diungkapkan dalam laporan tahunan K/L. Tema yang paling sering diungkapkan dalam laporan tahunan $\mathrm{K} / \mathrm{L}$ dan mencapai tingkat pengungkapan $100 \%$. Selanjutnya berturut-turut hingga urutan kesepuluh adalah struktur organisasi (78.95\%), informasi keuangan (63.16\%), visi dan misi (57.89\%), tugas pokok dan fungsi $(52.63 \%)$, informasi penghargaan yang diperoleh organisasi (52.63\%), profil pimpinan (47.37\%), informasi reformasi birokrasi (47.37\%), manajemen SDM (47.37\%), serta arah kebijakan dan strategi (42.11\%). Data lebih lengkap terkait hasil analisis ini dituangkan dalam Ilustrasi Tabel 2 sebagaimana terlampir.

Dari analisis tema informasi laporan tahunan K/L dapat disimpulkan laporan tahunan sebenarnya dapat menggantikan keberadaan LAKIP, mengingat informasi yang dituangkan dalam laporan tahunan lebih komprehensif dan memuat pula informasi kinerja. Namun demikian terdapat beberapa alternatif yang dapat dilakukan oleh pemerintah untuk mewujudkan transparansi dan akuntabilitas yang lebih baik. Pertama, pemerintah dapat menerbitkan peraturan yang menjadi pedoman dalam penyusunan LAKIP dengan muatan tema informasi yang lebih komprehensif. Kedua, pemerintah dapat menerbitkan peraturan yang mewajibkan K/L untuk menyusun laporan tahunan dan dilengkapi dengan pedoman pengungkapan 
informasi yang komprehensif serta menghapuskan kewajiban penyusunan LAKIP tahunan sementara LAKIP semesteran dan triwulanan tetap disusun. Ketiga, tetap mewajibkan penyusunan LAKIP dan menambah kewajiban bagi K/L untuk menyusun laporan tahunan.

Logika dominan yang mempengaruhi keputusan K/L untuk menyusun atau tidak menyusun dan mempublikasikan atau tidak mempublikasikan laporan tahunan adalah adanya "kewajiban". Seluruh responden kuesioner dan responden wawancara menyampaikan bahwa pertimbangan mereka untuk menyusun laporan tahunan adalah karena adanya kewajiban keterbukaan informasi publik sebagai konsekuensi karena anggaran bersumber dari dana publik. Sebagai contoh adalah tanggapan responden 3 sebagai berikut:

“.....publikasi dari laporan tersebut sangat penting karena merupakan kewajiban dari instansi pemerintah kepada publik serta hak bagi masyarakat untuk mengetahui kinerja dari instansi..."

Logika dominan tersebut bersifat multiple logics dengan adanya tuntutan profesionalisme dari stakeholder dan adanya kesempatan untuk mendapatkan insentif (remunerasi) lebih dari penerapan reformasi birokrasi. Berikut ini adalah pendapat responden 5 sebagai berikut:

“...K/L harus menunjukkan sikap profesional mereka dengan mempublish tiap kegiatan-kegiatan dan anggaran yang sudah mereka gunakan sebagai tanggung jawab ke masyarakat..."

Lebih lanjut responden 1 memiliki pendapat sebagai berikut:

“...tapi sebenernya kita pun sudah menyusun walaupun mereka nggak minta. Tapi karena itu salah satu dasar penilaian juga akhirnya kita bikin yang sebagus mungkin gitu loh ... mungkin dulu sebelumnya pake narasi biasa atau hanya bentuk buku tapi sekarang mungkin lebih banyak ada info grafis, ada foto-foto, dokumentasi, yang kayak gitu mungkin lebih menarik daripada hanya sekedar narasi yah, nah dengan gitu kan berarti menaikkan nilai kita juga kan ya, karna itu terus terang berpangaruh sama tukin..."

Dari sisi symbolic carriers, pedoman internasional tentang good governance/ transparansi dari Lembaga Internasional seperti World Bank, OECD dan CIPFA atau pedoman tentang good governance/transparansi dari negara maju seperti Amerika, Inggris dan Australia ternyata tidak menjadi pertimbangan sama sekali bagi K/L dalam mengambil keputusan penyusunan dan publikasi laporan tahunan. Seluruh responden baik kuesioner maupun wawancara sepakat mengenai hal ini. K/L lebih mempertimbangkan peraturan atau pedoman yang berlaku secara nasional. Peraturan Pemerintah Republik Indonesia Nomor 8 Tahun 2006 Tentang Pelaporan Keuangan Dan Kinerja Instansi Pemerintah disebutkan oleh seluruh reponden (100\%) sebagai pertimbangan dalam pengambilan keputusan, selanjutnya berturut-turut adalah Undang-Undang Nomor 1 Tahun 2004 tentang Perbendaharaan Negara (80.00\%), Peraturan Presiden Republik Indonesia Nomor 29 Tahun 2014 Tentang Sistem Akuntabilitas Kinerja Instansi Pemerintah (80.00\%), Peraturan Menteri Pendayagunaan Aparatur Negara dan Reformasi Birokrasi Republik Indonesia Nomor 53 Tahun 2014 Tentang Petunjuk Teknis Perjanjian Kinerja, Pelaporan Kinerja, dan Tata Cara Reviu Atas Laporan Kinerja Instansi Pemerintah (80.00\%), Pedoman Good Public Governance yang dirumuskan oleh Komite Nasional Kebijakan Governance (KNKG) (60.00\%) dan Undang-Undang Nomor 14 Tahun 2008 tentang Keterbukaan Informasi Publik (40.00\%).

Seluruh K/L yang menjadi responden penelitian menyampaikan bahwa mereka telah memiliki SOP yang digunakan untuk melakukan penyusunan laporan tahunan. Hal ini merupakan sisi positif yang telah dimiliki oleh K/L. Namun demikian terdapat beberapa kendala yang disebutkan terkait pelaksanaan SOP tersebut adalah adanya kendala dalam updating dan kompilasi data. Semakin banyak unit kerja yang dibawahi, maka proses updating dan kompilasi data menjadi lebih sulit untuk dilakukan. Berbeda halnya dengan K/L yang hanya memiliki sedikit unit kerja sebagaimana yang disampaikan oleh responden 1 berikut ini:

“... ya makanya kalo kita lebih simple. Nggak ada kendala sama sekali, jadi kebetulan yang mengerjakan itu ada di bagian Biro Perencanaan itu yang melakukan kompilasi yang mengolah data yang masuk dari kedeputian teknis kan kita ada 7 kedeputian teknis kan kecil lah ya, jadi mudah sih sebenernya. Mudah untuk menghimpun data tuh tidak sulit yah, karna dan kita kan kantornya cuma disini maksudnya nggak tersebar di Indonesia, jadi kita sangat mudah ya kalu mau minta apa, minta data apa atau update data itu nggak masalah..."

Faktor budaya organisasi seperti diadakannya rapat rutin bulanan, triwulanan dan semesteran dapat mendukung proses penyusunan laporan tahunan karena koordinasi dan update informasi dapat dilakukan dengan cepat dan terjadwal. Hal ini sebagaimana pendapat responden 1 berikut ini:

“...kita nggak pernah sama sekali nggak ada (kendala dalam penyusunan laporan tahunan), kebetulan kita tuh ada rapat rutin pimpinan jadi ada leader offsite meeting itu yang dilakukan tiga bulan atau empat bulan sekali, terus ada rapimja rapat pimpinan kinerja itu juga rutin setahun dua kali itu mengundang dari Menteri, sama semua pejabat 
eselon 1, sama ada perwakilan Asdep 1, dari masingmasing kedeputian teknis, tapi ada juga yang sampe eselon 2 ikut, jadi kita informasi itu ter update terus..."

Faktor lokal lainnya yang juga disebutkan oleh responden yang mempengaruhi proses penyusunan laporan tahunan adalah jumlah laporan yang semakin banyak, terdapat aturan-aturan baru, serta adanya mutasi dan rotasi. Sebagaimana disebutkan oleh respoenden 2 :

“...mengalami kendala. Biasanya terkait adanya aturan-aturan atau kebijakan-kebijakan baru ... jumlah laporan yang semakin meningkat / banyak. Serta jika ada pegawai pengelola yang mengalami mutasi / rotasi..."

Seluruh responden penelitian tidak menyebutkan bahwa terdapat masalah pada relational systems dalam organisasi mereka terkait penyusunan laporan tahunan. Selain itu, relational systems dengan aktor di luar lingkungan K/L juga tidak terjadi. Sehingga dengan demikian dapat disimpulkan bahwa para aktor lebih membangun komunikasi secara internal dalam mengambil keputusan untuk menyusun dan mempublikasikan laporan tahunan.

Dari sisi routines organisasi, seluruh K/L menyatakan bahwa mereka telah memiliki SOP dalam penyusunan laporan tahunan dan hanya menghadapi permasalahan pada waktu yang dibutuhkan untuk melakukan update dan kompilasi data. Sebagaimana yang diungkapkan oleh responden 3 sebagai berikut:

“...Ya kami memiliki SOP dalam penyusunan laporan tersebut. Kendala dalam penysunan adalah perlunya updating berkala..."

Dari sisi artifacts organisasi, seluruh K/L menyatakan bahwa mereka tidak memiliki permasalahan dalam hal dukungan teknologi dan sistem informasi, ketersediaan data dan informasi, kegiatan pendampingan/asistensi atau kendala teknis lainnya. Sebagaimana pendapat responden 3 sebagai berikut:

“... (K/L kami) memiliki sistem integrasi internal yang menyediakan data dari berbagai kegiatan dan capaiannya. Sistem ini dapat diakses seluruh pegawai dan tim penyusun dapat memperoleh data tersebut..."

Dari sudut pandang isomorphism, coercive isomorphism terjadi di $60 \% \mathrm{~K} / \mathrm{L}$ yang menjadi responden survey dan wawancara. K/L tersebut menyatakan bahwa terdapat pengaruh politik atau rekomendasi dari Lembaga Tinggi Negara atau K/L lain yang dipertimbangkan dalam pengambilan keputusan untuk menyusun atau tidak menyusun laporan tahunan. Sebagaimana pendapat responden 3 sebagai berikut:
“...UU KIP No.14 Tahun 2008 yang disusun oleh Komisi Informasi Pusat yang mengatur atas perlu tidaknya publikasi informasi yang ada di dalam instansi pemerintah kepada publik..."

Mimetic isomorphism terjadi di 60\% K/L yang menjadi responden survey dan wawancara. K/L tersebut menyatakan bahwa terdapat praktik/keputusan yang dilakukan/diambil oleh $\mathrm{K} / \mathrm{L}$ lain yang dipertimbangkan dalam pengambilan keputusan untuk menyusun atau tidak menyusun laporan tahunan. Sebagaimana diungkapkan oleh responden 1 sebagai berikut:

“...itu kayaknya Pak Ses kita kan orang keuangan tuh, Pak $X$, beliau tuh justru niru dari keuangan loh kebiasaannya Bu Sri Mulyani, dulu kita nggak ada rapat leader offsite meeting itu nggak ada, setelah Pak Ses masuk ini kita budayanya justru ngikutin keuangan, Cuma memang kita lingkupnya lebih kecil, jadi lebih enak sih sebenernya..., (jadi ada budaya yang terbawa juga), betul, sangat banyak sebetulnya tapi ya itu positive sih..."

Normative isomorphism terjadi di seluruh K/L yang menjadi responden survey dan wawancara. Seluruh responden menyatakan bahwa penyusunan laporan tahunan dilakukan sebagai bentuk pemenuhan hak dari masyarakat. Selain itu, untuk penyusunan laporan tahunan juga dilakukan untuk memenuhi tuntutan profesionalisme dari stakeholder. Sebagaimana pendapat responden 5 sebagai berikut:

“...K/L harus menunjukkan sikap profesional mereka dengan mempublish tiap kegiatan-kegiatan dan anggaran yang sudah mereka gunakan sebagai tanggung jawab ke masyarakat..."

Dari wawancara yang dilakukan dengan responden 1, diperoleh informasi bahwa pelaksanaan ajang penghargaan (award) akan dapat meningkatkan motivasi K/L untuk menyusun laporan tahunan. Berikut ini adalah pendapat responden 1:

“...Jadi kalo ada award kayak gitu kayaknya bisa meningkatkan motivasi, bisa. Jadi tuh kadangkadang menurut kita benar ternyata oh ini masih belum benar kan gitu kan, dengan adanya award gitu kan kita bisa saling tukar informasi kalo menurut saya, jadi kita terbuka aja harus bisa menerima kritik, ini kurang bagus, kurang lengkap, atau kurang rinci atau kurang apa nah mungkin dengan adanya ajang2 seperti itu bisa lebih memperbaiki dan kalo itu dilakukan dalam penyusunan ini kan jadi lebih bagus ya semua KL jadinya mereka semua kan juga termotivasi yah, kan pasti pengin dong masuk diberita oh kementerian ini menang penyusunan laporan tahunan itukan juga award nah kalo dapet award itu kan juga mempengaruhi nilai loh, lagi-lagi kesitu yah, kurang lebih itu..." 


\section{KESIMPULAN DAN SARAN}

Sebagian besar $(77,91 \%) \mathrm{K} / \mathrm{L}$ masih belum laporan tahunan tingkat $\mathrm{K} / \mathrm{L}$. Hal ini terjadi karena banyak K/L yang belum menyadari adanya kewajiban penyusunan laporan tahunan. Logika dominan yang berhasil dieksplorasi peneliti dari $\mathrm{K} / \mathrm{L}$ yang menyusun laporan tahunan adalah symbolic carriers di tingkat nasional yaitu adanya pandangan bahwa penyusunan laporan tahunan adalah suatu "kewajiban" yaitu untuk melaksanakan Undang-Undang Nomor 14 Tahun 2008 tentang Keterbukaan Informasi Publik. Logika dominan tersebut bersifat multiple logics dengan adanya tuntutan profesionalisme dari stakeholder dan adanya kesempatan untuk mendapatkan insentif (remunerasi) lebih dari penerapan reformasi birokrasi. Dengan demikian, jika pemerintah memutuskan untuk meningkatkan transparansi dan akuntabilitas melalui penyusunan laporan tahunan, pemerintah harus menyusun payung hukum yang tegas yang mewajibkan penyusunan laporan tahunan. Selain itu, pemerintah juga harus menanamkan kesadaran kepada seluruh K/L untuk memenuhi hak masyarakat atas keterbukaan informasi. Penyusunan laporan tahunan juga layak untuk dijadikan sebagai salah satu indikator yang dinilai dalam pencapaian reformasi birokrasi yang berpengaruh pada tingkat remunerasi suatu K/L.

Seluruh K/L yang menyusun laporan tahunan telah mengungkapkan informasi kinerja dalam laporan tahunan mereka. Dengan demikian, laporan tahunan K/L sebenarnya dapat menggantikan keberadaan LAKIP tahunan. Namun demikian terdapat beberapa alternatif keputusan yang dapat dilakukan oleh pemerintah yaitu membuat pedoman penyusunan LAKIP yang lebih komprehensif, mewajibkan penyusunan laporan tahunan dengan menghapuskan kewajiban penyusunan LAKIP tahunan atau mewajibkan penyusunan laporan tahunan dengan tidak menghapus kewajiban penyusunan LAKIP tahunan.

Dari sisi material carriers, tidak terbentuk relational systems antar $\mathrm{K} / \mathrm{L}$ dalam rangka penyusunan laporan tahunan. Relational systems yang terbentuk bersifat internal dan tidak terdapat permasalahan terkait hal ini. Sementara itu, terkait routines organisasi, keberadaan SOP dan adanya budaya rapat rutin organisasi sangat mendukung dan memudahkan organisasi untuk dapat menyusun laporan tahunan. Sedangkan terkait artifacts, K/L menyatakan bahwa mereka tidak menghadapi kendala dalam hal ini. Dengan demikian dapat disimpulkan bahwa untuk mendorong K/L agar menyusun laporan tahunan, pemerintah harus mendorong seluruh $\mathrm{K} / \mathrm{L}$ untuk menyusun SOP penyusunan laporan tahunan dan merekomendasikan agar seluruh K/L melakukan rapat koordinasi secara berkala untuk memantau dan meng-update progres kinerja.
Normative isomorphism terjadi di seluruh K/L yang menjadi responden penelitian, sedangkan coercive isomorphism dan mimetic isomorphism terjadi di $60 \% \mathrm{~K} / \mathrm{L}$. Dengan demikian, jika pemerintah ingin mendorong penyusunan laporan tahunan oleh seluruh $\mathrm{K} / \mathrm{L}$, pemerintah harus menanamkan pemahaman mengenai profesionalisme kepada seluruh K/L. Selain itu, Kementerian/Lembaga yang bertindak sebagai regulator seperti Kementerian Pendayagunaan Aparatur Negara dan Reformasi Birokrasi (Kemenpan-RB) dan Kementerian Informasi dan Komunikasi (Kominfo) harus terus mendorong dan menyarankan seluruh $\mathrm{K} / \mathrm{L}$ untuk melakukan publikasi laporan tahunan. Disamping itu, untuk meningkatkan motivasi dan pengaruh mimetic isomorphism dalam penyusunan laporan tahunan, pemerintah dapat melaksanakan ajang penghargaan (award) laporan tahunan untuk seluruh K/L.

\section{IMPLIKASI DAN KETERBATASAN}

Berdasarkan hasil temuan penelitian, pemerintah dapat mempertimbangkan berbagai alternatif keputusan. Jika diputuskan bahwa penyusunan laporan tahunan menjadi kewajiban bagi K/L, pemerintah harus mempersiapkan payung hukum yang jelas dan pedoman penyusunan yang terstandard. Selain itu, pemerintah juga harus mendorong setiap K/L untuk menyusun SOP internal dan untuk membudayakan rapat secara berkala. Di samping itu, pelaksanaan ajang penghargaan laporan tahunan (award) juga patut dipertimbangkan untuk meningkatkan motivasi K/L dalam menyusun laporan tahunan.

Keterbatasan dalam dalam penelitian ini bahwasanya masih terdapat banyak kekurangan khususnya terkait dengan terbatasnya jumlah responden. Untuk menyempurnakan penelitian ini, penelitian selanjutnya perlu menggunakan lebih banyak responden. Selain itu, penelitian ini juga terbatas pada penyusunan laporan tahunan tingkat $\mathrm{K} / \mathrm{L}$ dan tidak menganalisis penyusunan laporan tahunan pada tingkat Eselon I maupun Eselon II. Dengan demikian, untuk melengkapi penelitian ini, penelitian selanjutnya dapat dilakukan dengan mengambil unit Eselon I dan Eselon II sebagai objek penelitian.

\section{PENGHARGAAN}

Peneliti meyampaikan ucapan terima kasih yang sebesar-besarnya kepada seluruh responden penelitian yang telah meluangkan waktu dan pikirannya untuk menjawab pertanyaan penelitian di tengah kesibukan dan dinamika birokrasi yang semakin padat. Selain itu, peneliti juga menyampaikan terima kasih yang sebesar-besarnya kepada Tim Jurnal Indonesian Treasury Review yang telah memfasilitasi peneliti untuk menuangkan 
pemikiran dan ide yang mungkin dapat berkontribusi untuk perbaikan kebijakan publik, khususnya terkait penyusunan laporan tahunan.

\section{REFERENSI}

Badan Pusat Statistik. (2019). Indeks Demokrasi Indonesia (IDI) 2018. Diakses dari https://www.bps.go.id/website/materi_ind/ma teriBrsInd-20190729112338.pdf

Braun, V., \& Clarke, V. (2006). Using thematic analysis in psychology. Qualitative Research in Psychology, 3(2), 77-101. https://doi.org/10.1191/1478088706qp063oa

Bursa Efek Indonesia. (2019). Laporan Keuangan dan Tahunan. Diakses tanggal 29 October 2019, dari https://www.idx.co.id/perusahaantercatat/laporan-keuangan-dan-tahunan/

Cameron, W. (2004). Public accountability: effectiveness, equity, ethics. Australian Journal of Public Administration, 63(4), 59-67.

Dacin, M. T., Goodstein, J., \& Scott, W. R. (2002). Institutional theory and institutional change: introduction to the special research forum. The Academy of Management Journal, 45(1), 4455.

DiMaggio, P. J., \& Powell, W. W. (1983). The iron cage revisited institutional isomorphism and collective rationality in organizational fields. American Sociological Review, 48(2), 147-160. Retrieved from http://www.jstor.org/stable/2095101

Ellet, W. (2007). Case study handbook: how to read, discuss, and write persuasively about cases. Massachusetts, USA: Harvard Business School Press.

Friedland, R., \& Alford, R. R. (1991). Bringing society back in: symbols, practice, and institutional contradictions. The New Institutionalism in Organizational Analysis, 232-263.

George, A. L., \& Bennett, A. (2005). Case studies and theory development in the social sciences. Massachusetts, United States of America: Belfer Center for Science and International Affairs, Harvard University.

Greenwood, R., Hinings, C. R., \& Whetten, D. (2014). Rethinking institutions and organizations. Journal of Management Studies, 51(7), 12061220. https://doi.org/10.1111/joms.12070

Greenwood, R., \& Suddaby, R. (2006). Institutional entrepreneurship in mature fields: the big five accounting firms. The Academy of Management Journal, 49(1), 27-48. https://doi.org/10.5465/AMJ.2006.20785498
IFAC \& CIPFA. (2014). International Framework: Good Governance in The Public Sector.

KNKG. (2006). Pedoman Umum Good Corporate Governance Indonesia. Diakses dari http://www.knkgindonesia.org/dokumen/Pedoman-GoodPublic-Governance.pdf

KNKG. (2008). Pedoman Umum Good Public Governance Indonensia. Jakarta: Komite Nasional Kebijakan Governance.

KNKG. (2019). Tentang Kami. Diakses tanggal 27 September 2019, dari http://www.knkgindonesia.org/about

Komisi Informasi Pusat RI. (2018). Laporan Implementasi Keterbukaan Informasi Publik \& Penganugerahaan Keterbukaan Informasi Badan Publik Tahun 2018. Diakses dari https://komisiinformasi.go.id/wpcontent/uploads/2019/03/LaporanPenganugerahan-2018.pdf

Krippendorff, K. (2004). Content analysis: an introduction to its methodology. In physical review $B$ (2nd ed., Vol. 31). Thousand Oaks, California, USA: Sage Publications, Inc.

Kumar, R. (2011). Research methodology: a step-bystep guide for beginners (3rd ed.). New Delhi, India: SAGE Publications India Pvt Ltd.

Lepoutre, J. M. W. N., \& Valente, M. (2012). Fools breaking out: the role of symbolic and material immunity in explaining institutional nonconformity. Academy of Management Journal, 55(2), 285-313. https://doi.org/10.5465/amj.2008.0340

Maksudi, B. I. (2017). Dasar-dasar administrasi publik. Depok, Indonesia: Rajawali Pers.

Ntim, C. G., Soobaroyen, T., \& Broad, M. J. (2017). Governance structures, voluntary disclosures and public accountability: the case of UK higher education institutions. In Accounting, Auditing and Accountability Journal, 30(1), 65-118. https://doi.org/10.1108/AAAJ-10-2014-1842

OECD. (2002). Public sector transparency and accountability: making it happen. Paris: OECD Publishing. https://doi.org/10.1787/9789264176287-en

OPM, \& CIPFA. (2004). The Good Governance Standard for Public Services. Diakses dari www.opm.co.uk

Peraturan Otoritas Jasa Keuangan Nomor 29 /P0JK.04/2016 tentang Laporan Tahunan Emiten atau Perusahaan Publik. Jakarta: Otoritas Jasa Keuangan.

Peraturan Pemerintah Republik Indonesia Nomor 8 Tahun 2006 Tentang Pelaporan Keuangan dan 
Kinerja Instansi Pemerintah. Jakarta: Republik Indonesia.

Powell, W. W., \& DiMaggio, P. J. (1991). The new institutionalism in organizational analysis. Chicago, USA: The University of Chicago Press.

Reay, T., \& Hinings, C. R. (2009). Managing the rivalry of competing institutional logics. Organization Studies, 30(6), 629-652. https://doi.org/10.1177/0170840609104803

Ryan, C., Dunstan, K., \& Brown, J. (2001). The value of public sector annual reports and the contribution of annual reporting awards. Working Paper Series. Diakses dari http://www.victoria.ac.nz/sacl/centres-andinstitutes/cagtr/working-papers/WP03.pdf

Ryan, C., Dunstan, K., \& Brown, J. (2002). The value of public sector annual reports and annual reporting awards in organisational legitimacy. Accounting, Accountability and Performance, 8(1), 61-77.

Ryan, C., \& Ng, C. (2000). Public sector corporate governance disclosures: an examination of annual reporting practices in queensland. Australian Journal of Public Administration, 59(2), 11-23. https://doi.org/10.1111/14678500.00148

Scott, W. R. (1995). Institutions and organizations. California, USA: Sage Publications, Inc.

Scott, W. R. (2003). Institutional carriers: reviewing modes of transporting ideas over time and space and considering their consequences. Industrial and Corporate Change, 12(4), 879-894. https://doi.org/10.1093/icc/12.4.879

Sekaran, U., \& Bougie, R. (2016). Research methods for business: a skill-building approach (7th ed.). Chichester, West Sussex, United Kingdom: John Wiley \& Sons Ltd.

Shauki, E. R. (2018). “Converting Your Master/Ph.D. Thesis into a Journal Article" Handout Case Writing and Methodology, ECAM 809303. Universitas Indonesia.

The World Bank. (1989). Sub-Saharan Africa: From Crisis to Sustainable Growth. Diakses dari http://documents.worldbank.org/curated/en/ 498241468742846138/pdf/multi0page.pdf

The World Bank. (1992). Governance and Development.

Thornton, P. H., \& Ocasio, W. (1999). Institutional logics and the historical contingency of power in organizations: Executive succession in the higher education publishing industry, 19581990. American Journal of Sociology, 105(3), 801-843. https://doi.org/10.1086/210361
Thornton, P. H., Ocasio, W., \& Lounsbury, M. (2012). The institutional logics perspective: a new approach to culture, structure, and process. Oxford, United Kingdom: Oxford University Press.

Undang-Undang Republik Indonesia Nomor 8 Tahun 1995 tentang Pasar Modal. Jakarta: Republik Indonesia.

Undang-Undang Nomor 14 Tahun 2008 tentang Keterbukaan Informasi Publik. Jakarta: Republik Indonesia.

UNDP. (1997). Governance for Sustainable Human Development: A UNDP Policy Document. New York, USA.

Vardi, Y., \& Weitz., E. (2004). Misbehavior in organizations. Mahwah, New Jersey, USA: Lawrence Erlbaum Associates, Inc.

Yin, R. K. (2009). Case Study Research: Design and Methods. California, USA: Sage Publications (Vol. 5).

Zilber, T. B. (2013). Institutional logics and institutional work: should they be agreed? Research in the Sociology of Organizations, 39A, 77-96. 


\section{ILUSTRASI TABEL}

Tabel 2. Tema Informasi Dan Tingkat Pengungkapan Pada Laporan Tahunan K/L

\begin{tabular}{|c|c|c|c|}
\hline \multirow{2}{*}{ No } & \multirow{2}{*}{ Tema Informasi dalam Laporan Tahunan } & \multicolumn{2}{|c|}{$\begin{array}{c}\text { Jumlah dan \% K/L yang } \\
\text { mengungkapkan }\end{array}$} \\
\hline & & Jumlah & $\%$ \\
\hline 1 & Informasi Kinerja & 19 & $100.00 \%$ \\
\hline 2 & Struktur Organisasi & 15 & $78.95 \%$ \\
\hline 3 & Informasi Keuangan & 12 & $63.16 \%$ \\
\hline 4 & Visi dan Misi & 11 & $57.89 \%$ \\
\hline 5 & Tugas Pokok dan Fungsi & 10 & $52.63 \%$ \\
\hline 6 & $\begin{array}{l}\text { Informasi Penghargaan yang Diperoleh } \\
\text { Organisasi }\end{array}$ & 10 & $52.63 \%$ \\
\hline 7 & Profil Pimpinan & 9 & $47.37 \%$ \\
\hline 8 & Informasi Reformasi Birokrasi & 9 & $47.37 \%$ \\
\hline 9 & Manajemen SDM & 9 & $47.37 \%$ \\
\hline 10 & Arah Kebijakan dan Strategi & 8 & $42.11 \%$ \\
\hline 11 & Informasi Kerjasama Internasional & 6 & $31.58 \%$ \\
\hline 12 & Laporan Keterbukaan Informasi Publik & 5 & $26.32 \%$ \\
\hline 13 & Sistem Pengendalian Internal & 5 & $26.32 \%$ \\
\hline 14 & Nilai-Nilai Dasar & 4 & $21.05 \%$ \\
\hline 15 & Manajemen Teknologi Informasi & 4 & $21.05 \%$ \\
\hline 16 & $\begin{array}{l}\text { Penanganan Pengaduan (Wistleblowing } \\
\text { System) }\end{array}$ & 3 & $15.79 \%$ \\
\hline 17 & Kaleidoskop Organisasi & 2 & $10.53 \%$ \\
\hline 18 & Sejarah Organisasi & 2 & $10.53 \%$ \\
\hline 19 & Manajemen Aset & 2 & $10.53 \%$ \\
\hline 20 & Manajemen Risiko & 1 & $5.26 \%$ \\
\hline 21 & Informasi Tanggung Jawab Sosial & 1 & $5.26 \%$ \\
\hline 22 & Rencana Kegiatan Tahun Selanjutnya & 1 & $5.26 \%$ \\
\hline
\end{tabular}

Sumber: Diolah oleh peneliti dari Laporan Tahunan K/L 